\title{
Vulva Yerleşimli Ektopik Meme Dokusundan Gelişen Primer Meme Kanseri
}

\author{
Primary Breast Cancer Developing from the Vulva Located Ectopic Breast Tissu
}

\author{
Sami AÇAR ${ }^{1}$, Sibel GÜRDAL ${ }^{1}$ \\ 1. Zeynep Kamil Kadın ve Çocuk Hastalıkları Eğitim ve Araştırma Hastanesi, İstanbul, Türkiye \\ 2. Namık Kemal Üniversitesi, Tip Fakültesi, Tekirdăg, Türkiye
}

\section{$\ddot{O Z Z E T}$}

Giriș: Bilateral meme dokusu, embriyolojik açıdan ektodermal kökenli olup, inguinal bölge ile aksilla klvrımının ventrali arasinda gelişim gösterir. Ektopik meme dokusu primitif embriyonejenik süt çizgisi boyunca atrofinin oluşmadığ alanlarda, çoğunlukla da aksillada bulunur. Ikinci sikllkta vulvada görülür.

Olgu: Yazımızda, să̆ vulva labia majusta yer alan ektopik meme dokusundan gelişen primer meme kanserine sahip 66 yasinda postmenapozal bayan hasta sunulmustur. Uzun süredir vaginal bölgesinde var olduğunu bildiği kabarılıkta başlayan ve tedavi ile düzelmeyen yara șikayeti ile polikliniğe bașvurmuş, sistemik değerlendirmesinde patolojik bulgu saptanmamı ve tanisı yapilan cerrahi tedavi sonrasinda konulabilmiştir.

Sonuç: Ektopik meme dokusu, meme kanseri gelișimi için risk faktörüdür. Vulvada yerleşimli kitlesel dokularda bu olasılık her zaman akılda bulundurulmalıdır. Genellikle uzun süredir iyileşmeyen cilt lezyonlarma neden olarak bulgu verir. Literatürde az sayıda olgu sunumu ile yer alması nedeniyle, tedavi algoritması henüz netleșmemiştir. Bu bilgiler ıșığında hasta, bireysel olarak değerlendirilmeli ve tedavi planlamast multidisipliner ortamda yapılmalıdir.

Anahtar Kelimeler: ektopik meme, vulvar meme karsinomu, ektopik meme karsinomu, sentinel lenf nodu

\section{ABSTRACT}

Introduction: Bilateral breast tissue is of an embryological ectodermal origin and develops between the inguinal region and the ventral fold. Ectopic breast tissue is found in areas where atrophy does not occur along the primitive embryonic milk line, mostly in the axilla. It is seen in the vulva in the second frequency.

Case Report: In this article, a 66-year-old postmenopausal woman with primary breast cancer developing from ectopic breast tissue in the right vulva labia majus is presented. She applied to the outpatient clinic with the complaint of the wound that started in the swelling that she knew existed in the vaginal area for a long time and did not improve with treatment. In her systemic evaluation, no pathological finding was detected and the diagnosis was made after the surgical treatment.

Conclusion: Ectopic breast tissue is a risk factor for breast cancer development. This possibility should always be kept in mind in mass tissues located in the vulva. It usually gives signs by causing skin lesions that have not healed for a long time. The treatment algorithm is not clear yet, since it is included in the literature with a small number of case reports. In the light of this information, the patient should be evaluated individually and treatment planning should be done in a multidisciplinary environment.

Keywords: breast neoplasms, mammary glands, sentinel lymph node biopsy, vulva

\section{İletişim}

Sorumlu Yazar: Sami AÇAR

Adres: Zeynep Kamil, Dr. Burhanettin Üstünel Sokağı No:10, 34668 Üsküdar/İstanbul

Tel: +90 (216) 3910680

E-Posta: acarrsami@yahoo.com

Makale Geliş: 07.02.2020

Makale Kabul: 29.05.2020

DOI: http://dx.doi.org/10.16948/zktipb.686543

\section{GÍRIS}

Fazla sayıda meme (polimasti) veya meme başı (politeli) görülme insidansı \%0,1-1'dir. Polimasti, politeliden daha nadir görülür [1]. Aksesuar meme dokusunun insidans1 \% 2-6 'dır [2]. Genel populasyonda nadir görülür. Aksesuar meme dokusu meme karsinomasını tetikleyen nadir bir olaydır. Ektopik meme dokusu tüm meme bileşenlerini içerebilir ve normal yerleşimli meme dokusu gibi fizyolojik stres ve hormonal uyarılara karşı benzer yollar ile yanıt verebilir. Sonuç olarak benign veya malign meme dokusu patolojisi gösterebilir. Vulvada yer alan ektopik meme dokusundan invaziv kanser gelişme insidans $1 \% 4$ düzeyindedir [3]. Bat1 literatüründe 1872 ile 2018 yılları arasında 28 vaka bildirilmiştir.

\section{OLGU}

66 yaşında postmenapozal kadın hasta, vulvasında düzelmeyen yara şikayeti ile polikliniğe başvurdu. Vulva inspeksiyonunda pedikülü bulunan, hafif derecede ülseröz lezyon saptand. Çevredeki deri normal görünümdeydi ve tanı koydurucu ek patolojik bulgusu yoktu. Palpe edilebilen inguinal lenf nodu saptanmadi. Serviksin spekulum muayenesi doğal görünümdeydi. Ülseröz lezyondan alınan punch biyopsi tanı koydurucu özellikte değildi. İntravenöz kontrastlı bilgisayarlı tomografide karın ve pelvis görüntüsünde metastaz bulgusu görülmedi. Kolonoskopisi doğal, serum karsinoma antijen-125 (CA-125) düzeyi normal seviyedeydi. Metastatik gelișim göstermediği düşünülen lezyon, $1 \mathrm{~cm}$ 'lik temiz cerrahi sınır sağlanacak şekilde eksize edildi. Frozen incelemede, cerrahi sinırların temiz olduğu ve anjiolenfatik invazyon bulunmadığı belirtildi. Pedikülü bulunan ülseröz lezyon için inguinal lenfadenektomi yapılmadi. Piyesin patolojik incelemesi sonrasında, 1,9*1,8*1,3 cm'lik kitle oluşturan ve $0,5 \mathrm{~cm}$ derinliği bulunan, grade-4 invaziv adenokarsinom varlığ1 raporlandı. Örneğe ait parafin dokularda immün peroksidaz çalışmaları, CK-7, ER ve GCDFP-15 ve mammoglobin moleküllerine karşı antikorlar kullan1larak yapıld1. Tümör hücreleri CK-7, ER, mammaglobin antikorlarına karşı kuvvetli pozitif sonuç verdi. Tümör hücrelerinin morfolojisi ve immünoprofili meme kanseri için anlamlı bulundu. Ayrıca herhangi bir glandular yapı ile ilişkisi saptanmadı ve Paget's hastalığı dişland.

Hasta ameliyatı takip eden gün taburcu edildi. Bir aylık izlem sonrasında yaranın iyileşmiş olduğu ve başka bir lezyonun bulunmadığı gözlendi. Onkoloji konseyinde görüşülen hastaya adjuvan radyoterapi verilmesine karar verildi. Sistemik tedavi uygulanmadi. 


\section{TARTIȘMA}

Embriyogenezisin altıncı haftasında epidermal hücreler, alttaki mezenkimal doku içine ilerler ve aksilladan inguinal bölgeye kadar uzanan ilk meme kabartısını oluştururlar. Bu oluşumun dördüncü interkostal alan üzerindeki kısmı gelişirken diğer bölümü atrofiye uğrayarak kaybolur. Bu gerileme meydana gelmezse ektopik meme dokusu oluşur ve bu da primitif süt çizgisi boyunca herhangi bir noktada olabilir [3]. Ektopik meme dokusu, normal meme dokusu gibi fizyolojik ve patolojik süreçlerden etkilenir. Dolayısıyla vakamızda olduğu gibi vulvada yer alan ektopik meme dokusundan da invaziv kanser gelişebilir ve bugün için literatürde yaklaşık 28 vaka vardır. Al-Mansouri ve arkadaşlarının yaptığ 1 derlemede bu vakaların en sik ağrısız kitle ya da ele gelen tek nodüler lezyon varlığı ile polikliniğe başvurduğu ifade edilmiştir. Ayrıca lezyonların en çok labium majusta bulunduğu, kitlelerin çaplarının 1,5$2 \mathrm{~cm}$ arasında değişim gösterdiği, hastaların 45-82 yaş aralığında ve ortalama 62 yaş düzeyinde olduğu belirtilmiştir. Patolojik olarak en sik invaziv duktal karsinom alt tipinin görüldüğü vurgulanmıştır [4]. Prognozun ve tedavi seçeneğinin netleştirilmesi amaciyla, mevcut lezyonun primer vulva kanseri ile vulvaya metastaz yapmış ya da vulvada gelişen diğer kanser türlerinden ayrımının yapılması gerekmektedir. Bu amaçla lezyonun meme kanseri ile uyumlu histolojik paternde olup olmadığına bakılır. Ayrıca östrojen ve/veya progesteron reseptörlerinin durumu, immunohistokimyasal açıdan meme kanseri ile ilgili olan mammoglobulin, CK 7, GCDFP, CEA gibi belirteçleri ve lezyonun bulunduğu alanda normal meme dokusunun ya da karsinoma in situ varlığının bulunup bulunmaması değerlendirilir [5]. Hastamızda da eksizyon piyesinin komşuluğunda normal meme dokusunun varlığ 1 patolojik incelemede gösterilmiştir. Ayrıca tanısal amaçlı ER (östrojen reseptörü), PR (progesteron reseptörü), gross cystic fluid protein (GCDFP), HER-2 neu, sitokeratin (CK7) ve müsin glikoprotein antikor, ve DAS-1 olarak adlandırılan moleküllerine karşı geliştirilen antikor testleri uygulanmıştır. Bu grupta östrojen, progesteron ve GCDFP, meme kanseri için son derece özgündür ve hastamızda pozitif, HER 2 sonucu negatiftir.

$\mathrm{Bu}$ tür lezyonların oldukça nadir görülüyor olması ve belirlenmiş bir tedavi algoritmasının olmamas1 sebebiyle, normal meme kanseri tedavi sürecinden ayrı olarak ele alınması faydalı olabilir. Cerrahi tedavi seçenekleri duktal karsinoma in situ varlığında geniş lokal eksizyondan, invaziv kanser varlığında radikal vulvektomi ile bilateral inguinal lenf nodu diseksiyonuna kadar geniş bir aralıkta yer alır [6,7]. Abbott ve Ahmed radikal cerrahi tedavi yöntemlerinin yerine, özellikle yaşlı bireylerde Mohs mikrografik cerrahisinin, deride yer alan tümörler için alternatif yöntem olabileceğini bildirmişlerdir [8]. Ishigaki ve arkadaşları, benzer bir durumda, bilateral inguinal lenf nodu diseksiyonununu takiben pelvik lenf nodu diseksiyonuna karar vermek adına sentinel lenf nodu çalışmışlar ve inguinal lenf nodlarının pozitif olması durumunda pelvik lenf nodlarının diseksiyonunu ve/veya pelvik rad- yoterapi tedavisinin önerilmesi gerektiği sonucuna varmışlardır. Bu çalışma, benzer klinik durumlarda sentinel lenf nodu çalışılmasının rutin hale gelmesi adına ümit vericidir. Yine bu çalışmanın ilginç bir noktası da, aynı hastanın HER2 (+)'liği nedeniyle transtuzumab kullanılan ilk vaka olmasidır [9]. ER pozitif olan hastalara ise aromataz inhibitörü kullanması önerilir [7,9]. Kemoterapi rejimi hastanın evresine ve patoloji sonucuna göre bireyselleştirilmiş olarak verilir. Adjuvan tedavi almayan hastalarda ortalama sağ kalım 1-4 ay iken, invaziv duktal karsinomu patolojisi olan adjuvan tedavi almış vulva yerleşimli primer meme kanserinde en uzun sağ kalım 48 ay kadardır [10]. İngilterede 81 yaşındaki bayan hastada vulvada görülen primer lobuler meme kanseri için anastrozol kullanılmış ve postmenapozal kadınlarda uygulanan tamoksifen kadar etkili bir ilaç olduğu görülmüştür.

\section{SONUÇ}

Vulvada primer meme adenokarsinom tanısin1, konuyla ilgili her klinisyen akılda bulundurmalıdır. Konu üzerine literatür bilgisi şu an için yetersizdir. $\mathrm{Bu}$ tür hasta gruplarının tedavisinin iyi bir şekilde yönlendirilmesi için günümüzde ne yazık ki güçlü kanitlar ortaya konamamaktadır. Bununla beraber belirtilen histolojik veriler bu kanserlerin meme kanserlerine benzer olduğunu teyit etmektedir. Cerrahi tedavide etkili bulunan ve morbidite oranını düşürecek olan sentinel lenf nodu çalışılmasının rutin haline gelmesi beklenmelidir. Tedavi planının multidisipliner ortamda, hastaya göre bireyselleştirilmiş olarak verilmesi akılcı olacaktır.

\section{KAYNAKLAR}

1- Pryor LS, Lehman JA Jr, Workman MC. Disorders of the female breast in the pediatric age group. Plast Reconstr Surg.2009;124:50e-60e.

2- Duvvur S, Sotres M, Lingam K, Srinivasan J. Ectopic breast tissue of the vulva. J Obstet Gynaecol 2007; 27: 530-531.

3- Fracchioli S, Puopolo M, Rigault de la Longrais I et al. Primary "breast-like" cancer of the vulva: A case report and critical review of the literature. Int J Gynecol Cancer 2006; 16 (S1): 423-428.

4- Al-Mansouri L, Poursoltan P, Simons M, Muljono A, Boyages J. Primary breast cancer of the vulva: A case report and literature review. $J$. Obstet. Gynaecol. Res. 2018; doi:10.1111/jog.13778

5- North J, Perez D, Fentiman G, Sykes P, Dempster A, Pearse M. Primary breast cancer of the vulva: Case report and literature review. Aust $N Z J$ Obstet Gynaecol 2007; 47: 77-79.

6- Benito V, Arribas S, Martínez D, Medina N, Lubrano A, Arencibia O. Metastatic adenocarcinoma of mammary-like glands of the vulva successfully treated with surgery and hormonal therapy. J Obstet Gynaecol Res 2013; 39: 450-454.

7- Baykal C, Dünder I, Turkmen I, Ozyar E. An unusual case of mammary gland-like carcinoma of vulva: Case report and review of literature. Eur J Gynaecol Oncol 2015; 36: 333-334.

8-Abbott J, Ahmed I. Adenocarcinoma of Mammary-Like Glands of the Vulva Report of a Case and Review of the Literature. Am J Dermatopathol 2006;28:127-133

9- Ishigaki T, Toriumi Y, Nosaka R, Kudou R, Imawari Y, Kamio M. Primary ectopic breast cancer of the vulva, treated with local excision of the vulva and sentinel lymph node biopsy: A case report. Surg Case Rep 2017; 3 .

10- Lopes A, Louis JS, Balancin ML, Nogueira-Rodrigues A, Silva LC, Paulino E. A rarepresentation of primary breast carcinoma in the vulva: A case report and literature review. Clin Breast Cancer 2017; 18: e291e294. 